\title{
Nocardia jejuensis sp. nov., a novel actinomycete isolated from a natural cave on Jeju Island, Republic of Korea
}

\author{
Soon Dong Lee
}

Correspondence

Soon Dong Lee

sdlee@cheju.ac.kr
Department of Science Education, Cheju National University, Jeju 690-756, Republic of Korea
Recently, improved classification based on a polyphasic approach has provided an invaluable framework for the recognition of additional species from diverse substrates, and has led to a rapid increase in the number of described species. Most of the recently described Nocardia species were isolated from clinical materials (Yassin et al., 2001; Kageyama et al., 2004) or environmental samples, such as soil (Zhang et al., 2003; Kämpfer et al., 2004), rivers (Maldonado et al., 2000) and activated sluge (Lemmer \& Kroppenstedt, 1984).

During the investigation of the biodiversity of cave bacteria, a novel actinomycete, strain $\mathrm{N} 3-2^{\mathrm{T}}$, was isolated from a soil sample inside a natural cave on Jeju Island, Republic of Korea, by using starch casein agar [SCA; $1 \%$ soluble starch, $0.03 \%$ casein, $0.2 \% \mathrm{KNO}_{3}, 0.2 \% \mathrm{NaCl}, 0.002 \% \mathrm{CaCO}_{3}$, $0.005 \% \mathrm{MgSO}_{4} .7 \mathrm{H}_{2} \mathrm{O}, 0.001 \% \mathrm{FeSO}_{4} .7 \mathrm{H}_{2} \mathrm{O}$ and $1.8 \%$ agar $(\mathrm{pH} 7 \cdot 2)]$ and maintained as mycelial fragments or spores in $20 \%(\mathrm{v} / \mathrm{v})$ glycerol or as lyophilized cells. For bacterial isolation, a soil sample $(1 \mathrm{~g})$ was placed into a sterile plastic tube containing $9 \mathrm{ml}$ sterile distilled water. After mixing,

Published online ahead of print on 28 October 2005 as DOI 10.1099/ ijs.0.63866-0.

The GenBank/EMBL/DDBJ accession number for the $16 \mathrm{~S}$ rRNA gene sequence of strain N3-2 ${ }^{\top}$ is AY964666.

Extended version of the neighbour-joining tree showing the relationship between strain N3-2 ${ }^{\top}$ and representatives of the genus Nocardia is available as supplementary material in IJSEM Online. aliquots $(100 \mu \mathrm{l})$ of the serial diluent of the samples were transferred onto SCA and the agar plates were incubated at $30^{\circ} \mathrm{C}$ for 14 days. The organism was subjected to phenotypic and genotypic characterization in order to unravel its taxonomic status. The resultant data supported the conclusion that the organism be classified as a novel species of the genus Nocardia.

Cultural and morphological characteristics were observed by using the various culture media, yeast extract/malt extract agar (ISP 2 medium), oatmeal agar (ISP 3 medium), ISP 4 medium (Shirling \& Gottlieb, 1966), trypticase soy agar (Difco) and nutrient agar (Difco). The degree of growth, the colour of aerial and vegetative mycelium and the presence of diffusible pigments of the organism were recorded on all tested media, incubated for 14 days at $30^{\circ} \mathrm{C}$, after which cell morphology was observed by using a light microscope. For electron microscopy, agar blocks with growth were fixed with $1 \%$ osmium tetroxide, dehydrated through a graded series of ethanol and isoamyl acetate and critical-pointdried. The gold-coated specimen was observed using a Hitachi S-2460 scanning electron microscope.

Carbohydrate utilization was tested using ISP 9 medium (Shirling \& Gottlieb, 1966) including each filter-sterilized carbon source at a final concentration of $1 \%(\mathrm{w} / \mathrm{v})$. The growth temperature and $\mathrm{pH}$ were tested at $10-45^{\circ} \mathrm{C}$ and $4 \cdot 1-10 \cdot 1$, respectively. Gram and acid-fast staining were performed as previously described (Collins et al., 1995). 
Oxidase activity was determined by monitoring the oxidation of tetramethyl-p-phenylenediamine on filter-paper discs. Catalase activity was determined with a $3 \%(\mathrm{v} / \mathrm{v})$ hydrogen peroxide solution. Urease activity was determined by a colour change in Bacto urea broth (Difco). The production of hydrogen sulfide was detected on peptone iron agar (Difco). DNA hydrolysis was observed by using DNase test agar with methyl green (Difco). Nitrate reduction, gelatin liquefaction and hydrolysis of aesculin and starch were examined by using previously described methods (MacFaddin, 1980). Decomposition of adenine, elastin, hypoxanthine, DL-tyrosine and xanthine was examined using the method described by Gordon et al. (1974). Sodium chloride tolerance was determined at concentrations of $0-7 \%(\mathrm{w} / \mathrm{v})$ on yeast extract/malt extract agar.

For chemical analysis, the strain was cultivated in YMG broth $(0 \cdot 4 \%$ yeast extract, $1 \%$ malt extract and $0.4 \%$ glucose; $\mathrm{pH} 7 \cdot 0$ ) for 3 days at $30^{\circ} \mathrm{C}$ with shaking. The isomer of diaminopimelic acid, the acyl type of cell wall and the sugar composition of whole-cell walls were analysed according to previously described methods (Staneck \& Roberts, 1974; Saddler et al., 1991; Uchida \& Aida, 1984). Purified menaquinones were identified by HPLC (Kroppenstedt, 1985). The phospholipid composition was determined by a previously described method (Minnikin et al., 1977). Analysis of mycolic acids was performed using a previously described method by Minnikin et al. (1980). Cellular fatty acid methyl esters were prepared by a previously described method (Minnikin, 1988) and analysed by gas chromatography with a Hewlett Packard model 6850 gas chromatograph as previously described (Lee et al., 2000).

Chromosomal DNA was extracted using a previously described method (Hopwood et al., 1985). The 16S rRNA gene of strain N3-2 ${ }^{\mathrm{T}}$ was amplified by PCR and directly sequenced using an ABI Prism BigDye Terminator cycle sequencing kit (Applied Biosystems) and an automatic DNA sequencer (model 3730xl; Applied Biosystems). The sequence determined in this study was aligned with reference sequences of the genus Nocardia by using CLUSTAL X program (Thompson et al., 1997) and the alignment was manually optimized by comparison with the secondary structure of the Escherichia coli sequence (Brosius et al., 1978). Phylogenetic analyses were performed using three tree-making algorithms, namely neighbour-joining (Saitou \& Nei, 1987), maximum-likelihood (Felsenstein, 1981) and maximum-parsimony (Fitch, 1971) methods. A phylogenetic tree was reconstructed from evolutionary distances calculated by the method described by Jukes \& Cantor (1969) using the neighbour-joining method. The tree topology was evaluated by bootstrap analysis (Felsenstein, 1985) of the neighbour-joining dataset, using 1000 replications. The $\mathrm{G}+\mathrm{C}$ content of the DNA was determined by HPLC (Mesbah et al., 1989).

It was revealed from chemotaxonomic analyses that strain $\mathrm{N} 3-2^{\mathrm{T}}$ contained chemical characters that were consistent with those of the genus Nocardia. Whole-cell hydrolysates of the isolate were rich in meso-diaminopimelic acid, arabinose and galactose [wall chemotype IV (Lechevalier \& Lechevalier, 1970)]. The polar-lipid profile contained phosphatidylethanolamine, phosphatidylinositol and diphosphatidylglycerol as characteristic phospholipids [phospholipid type PII pattern (Lechevalier et al., 1977)]. The predominant menaquinone was a tetrahydrogenated menaquinone with eight isoprene units, in which the two terminal isoprene moieties were cyclized $\left[\mathrm{MK}-8\left(\mathrm{H}_{4, \omega-\mathrm{cycl}}\right)\right]$. It was shown from one-dimensional TLC of whole-cell methanolysates that two lipid spots were identified; the lower one corresponded to mycolic acids (relative $R_{f}$ value of 0.47 ) and the higher one to non-hydroxylated fatty acids. The fatty-acid profile contained a mixture of straight-chain saturated, unsaturated and branched fatty acids, including the major components (as a proportion of the total fatty acids) hexadecanoic acid $\left(\mathrm{C}_{16: 0} ; 31 \cdot 3 \%\right)$, 10-methyloctadecanoic acid (tuberculostearic acid, 10-methyl- $\left.\mathrm{C}_{18: 0} ; 31 \cdot 1 \%\right)$, octadecanoic acid $\left(\mathrm{C}_{18: 0} ; 12 \cdot 7 \%\right)$, cis-9-octadecenoic acid (cis-9- $\mathrm{C}_{18: 1}$; $12 \cdot 1 \%)$ and hexadecenoic acid $\left(\mathrm{C}_{16: 1} ; 7 \cdot 0 \%\right)$. The mixture of fatty acid methyl esters also contained tetradecanoic acid $\left(\mathrm{C}_{14: 0}, 2 \cdot 8 \%\right)$, pentadecanoic acid $\left(\mathrm{C}_{15: 0}, 1 \cdot 7 \%\right)$ and heptadecanoic acid $\left(\mathrm{C}_{17: 0}, 1.3 \%\right)$ as minor components. The DNA base composition of strain N3-2 ${ }^{\mathrm{T}}$ was $69 \cdot 6 \mathrm{~mol} \%$ $\mathrm{G}+\mathrm{C}$ as determined by HPLC.

The 16S rRNA gene sequence of strain N3-2 ${ }^{\mathrm{T}}$ was determined by direct sequencing of the purified PCR product. The nearly complete sequence, consisting of a continuous stretch of $1392 \mathrm{nt}$, was aligned with the sequences of 41 type strains of Nocardia species with validly published names. A phylogenetic tree (Fig. 1), constructed by the

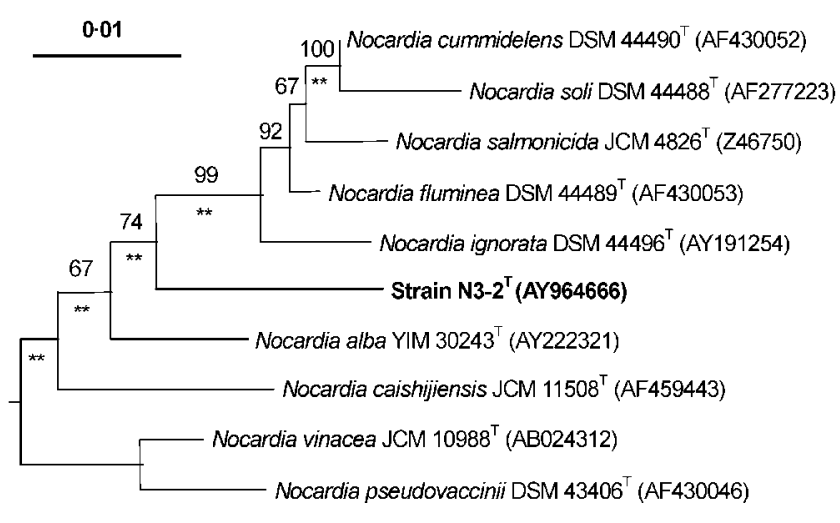

Fig. 1. Abbreviated neighbour-joining tree based on $16 \mathrm{~S}$ rRNA gene sequence showing the relationship between strain N3-2 ${ }^{\top}$ and representatives of the genus Nocardia (the full version is available as Supplementary Fig. S1 in IJSEM Online). Double asterisks indicate branches of the tree that were recovered using both maximum-likelihood (Felsenstein, 1981) and maximumparsimony (Fitch, 1971) tree-making algorithms. Numbers at nodes indicate percentages of bootstrap support based on a neighbour-joining analysis of 1000 resampled datasets (only values greater than $60 \%$ are indicated). Bar, $1 \mathrm{nt}$ substitution per $100 \mathrm{nt}$. 
neighbour-joining method, showed that the organism is a member of the genus Nocardia but forms a distinct clade between the Nocardia salmonicida cluster (Maldonado et al., 2000; Yassin et al., 2001), which contains Nocardia cummidelens, N. fluminea, N. salmonicida, N. ignorata and $N$. soli, and the N. alba branch (Li et al., 2004). The robustness of this clade was supported by a moderately high bootstrap value $(74 \%)$. The levels of $16 \mathrm{~S}$ rRNA gene sequence similarity to the phylogenetic neighbours were $96 \cdot 6-97 \cdot 4 \%$, whereas the sequence similarity to the other type strains of Nocardia species ranged from $94 \cdot 4$ to $97 \cdot 0 \%$. Strain N3-2 ${ }^{\mathrm{T}}$ shared a relatively low value of $16 \mathrm{~S}$ rRNA gene sequence similarity $(97 \cdot 4 \%)$ with its nearest relatives, N. cummidelens and $N$. alba, indicating that the organism merits separate species status within the genus Nocardia.

Strain N3-2 $2^{\mathrm{T}}$ showed good growth on all the media tested and formed a well-developed, branched substrate mycelium that fragmented into irregular rod-shaped elements. The reverse side of colonies was orange-coloured. The welldeveloped, white to pinkish aerial mycelium fragmented into irregular rod-shaped elements. Diffusible pigments were not produced on any media tested. Strain N3-2 utilized a broad range of carbohydrates and alcohols as sole carbon sources. Growth occurred between 10 and $37^{\circ} \mathrm{C}$. The $\mathrm{pH}$ range for growth was $4 \cdot 1-10 \cdot 1$. Growth occurred in the presence of $0-4 \% \mathrm{NaCl}$ but not in $5 \% \mathrm{NaCl}$. Strain $\mathrm{N} 3-2^{\mathrm{T}}$ can be readily distinguished from its phylogenetic neighbours within the genus Nocardia using a range of phenotypic properties (Table 1).

Table 1. Phenotypic characteristics that differentiate strain Nocardia jejuensis N3-2 ${ }^{\top}$ from its phylogenetic neighbours

Strains: 1, N. jejuensis N3-2 $2^{\mathrm{T}} ; 2$, N. alba YIM $30243^{\mathrm{T}} ; 3$, N. cummidelens DMS $44490^{\mathrm{T}} ; 4$, N. fluminea DSM $44489^{\mathrm{T}} ; 5, N$. ignorata DSM $44496^{\mathrm{T}}$; 6, N. salmonicida JCM 4826 $;$ 7, N. soli DSM $44488^{\mathrm{T}}$. Data were taken from Isik et al. (1999), Li et al. (2004), Maldonado et al. (2000) and Yassin et al. (2001). +, Positive; - , negative; $\mathrm{W}$, weak; ND, not determined.

\begin{tabular}{|c|c|c|c|c|c|c|c|}
\hline Characteristic & 1 & 2 & 3 & 4 & 5 & 6 & 7 \\
\hline \multicolumn{8}{|c|}{ Growth on sole carbon sources } \\
\hline L-Rhamnose & - & + & - & + & - & - & + \\
\hline myo-Inositol & + & + & - & - & - & - & - \\
\hline D-Mannitol & - & + & - & - & + & + & - \\
\hline D-Sorbitol & + & - & - & - & $\mathrm{W}$ & + & - \\
\hline L-Arabinose & + & - & ND & ND & - & - & ND \\
\hline Maltose & - & + & ND & $\mathrm{ND}$ & + & - & ND \\
\hline \multicolumn{8}{|l|}{ Decomposition of: } \\
\hline Casein & + & $\mathrm{ND}$ & - & - & - & - & - \\
\hline Elastin & - & $\mathrm{ND}$ & - & - & - & - & - \\
\hline Hypoxanthine & + & $\mathrm{ND}$ & - & - & - & - & - \\
\hline DL-Tyrosine & + & $\mathrm{ND}$ & - & + & - & + & - \\
\hline Xanthine & - & $\mathrm{ND}$ & - & - & - & + & - \\
\hline Growth at $\mathrm{pH} 4 \cdot 1$ & + & $\mathrm{ND}$ & - & - & $\mathrm{ND}$ & ND & - \\
\hline
\end{tabular}

On the basis of phenotypic and genotypic data, the isolate merits novel species status in the genus Nocardia, for which we propose the name Nocardia jejuensis sp. nov.

\section{Description of Nocardia jejuensis sp. nov.}

Nocardia jejuensis (je.ju.en'sis. N.L. fem. adj. jejuensis of Jeju Island, Republic of Korea, from which the type strain was isolated).

Aerobic, Gram-positive, catalase-positive, slightly acidalcohol-fast, non-motile. Forms a well-developed and branched substrate mycelium that fragments into irregular rod-shaped elements. Colour of the substrate mycelium is orange. The white to pinkish aerial mycelium fragments into rod-shaped elements. Urease-positive. Nitrate is reduced to nitrite. Gelatin liquefaction does not occur. Aesculin, casein and DNA are hydrolysed but not starch. Growth occurs at $10-37^{\circ} \mathrm{C}$. The $\mathrm{pH}$ range for growth is $4 \cdot 1-10 \cdot 1$. Growth occurs in the presence of $0-4 \% \mathrm{NaCl}$ but not in $5 \% \mathrm{NaCl}$. Hypoxanthine and DL-tyrosine are degraded but not elastin or xanthine. L-Arabinose, D-fructose, D-glucose, inulin, D-lactose, D-melezitose, melibiose, L-ribose, salicin, sucrose, glycerol, myo-inositol and D-sorbitol are used as sole carbon and energy sources, but not D-arabinose, D-cellobiose, D-galactose, maltose, D-mannose, methyl $\alpha$-D-glucoside, methyl $\alpha$-D-mannoside, D-raffinose, L-rhamnose, L-sorbose, D-trehalose, D-xylose, adonitol, 2,3-butanediol, dulcitol, meso-erythritol, D-mannitol, 1,2-propanediol or D-xylitol. Type IV cell wall (meso-diaminopimelic acid, arabinose and galactose). Predominant menaquinone is $\mathrm{MK}-8\left(\mathrm{H}_{4}\right.$, $\omega$-cycl $)$. Phospholipid profile contains phosphatidylethanolamine, phosphatidylinositol and diphosphatidylglycerol (phospholipid type PII pattern). Mycolic acids are present. Predominant cellular fatty acids are $\mathrm{C}_{16: 0}(31 \cdot 3 \%), 10$ methyl- $\mathrm{C}_{18: 0}(31 \cdot 1 \%), \mathrm{C}_{18: 0}(12 \cdot 7 \%)$, cis-9- $\mathrm{C}_{18: 1}(12 \cdot 1 \%)$ and $\mathrm{C}_{16: 1}(7 \cdot 0 \%)$. The $\mathrm{G}+\mathrm{C}$ content of the DNA is $69 \cdot 6 \mathrm{~mol} \%$.

The type strain, N3-2 ${ }^{\mathrm{T}}\left(=\mathrm{JCM} 13281^{\mathrm{T}}=\mathrm{NRRL} B-24430^{\mathrm{T}}\right)$, was isolated from a natural cave on Jeju Island, Republic of Korea.

\section{Acknowledgements}

This work was supported by Korean Research Foundation Grant (KRF-2003-041-C00316). The author is indebted to H. L. Yang for the analysis of cellular fatty acids.

\section{References}

Brosius, J., Palmer, M. L., Kennedy, P. J. \& Noller, H. F. (1978). Complete nucleotide sequence of a $16 \mathrm{~S}$ ribosomal RNA gene from Escherichia coli. Proc Natl Acad Sci U S A 75, 4801-4805.

Collins, C. H., Lyne, P. M. \& Grange, J. M. (1995). Collins and Lyne's Microbiological Methods. Oxford: Butterworth-Heinemann.

Felsenstein, J. (1981). Evolutionary trees from DNA sequences: a maximum likelihood approach. J Mol Evol 17, 368-376. 
Felsenstein, J. (1985). Confidence limits on phylogenies: an approach using the bootstrap. Evolution 39, 783-791.

Fitch, W. M. (1971). Towards defining the course of evolution: minimum change for a specific tree topology. Syst Zool 20, 406-416.

Gordon, R. E., Barnett, D. A., Handerhan, J. E. \& Pang, C. H.-N. (1974). Nocardia coeliaca, Nocardia autotrophica, and the nocardin strain. Int J Syst Bacteriol 24, 54-63.

Hopwood, D. A., Bibb, M. J., Chater, K. F. \& 7 other authors (1985). Genetic Manipulation of Streptomyces, a Laboratory Manual. Norwich: John Innes Foundation.

Isik, K., Chun, J., Hah, Y. C. \& Goodfellow, M. (1999). Nocardia salmonicida nom. rev., a fish pathogen. Int J Syst Bacteriol 49, 833-837.

Jukes, T. H. \& Cantor, C. R. (1969). Evolution of protein molecules. In Mammalian Protein Metabolism, pp. 21-132. Edited by H. N. Munro. New York: Academic Press.

Kageyama, A., Poonwan, N., Yazawa, K., Mikami, Y. \& Nishimura, K. (2004). Nocardia asiatica sp. nov., isolated from patients with nocardiosis in Japan and clinical specimens from Thailand. Int J Syst Evol Microbiol 54, 125-130.

Kämpfer, P., Buczolits, S., Jäckel, U., Grün-Wollny, I. \& Busse, H.-J. (2004). Nocardia tenerifensis sp. nov. Int J Syst Evol Microbiol 54, 381-383.

Kroppenstedt, R. M. (1985). Fatty acid and menaquinone analysis of actinomycetes and related organisms. In Chemical Methods in Bacterial Systematics, pp. 173-199. Edited by M. Goodfellow \& D. E. Minnikin. London: Academic Press.

Lechevalier, M. P. \& Lechevalier, H. (1970). Chemical composition as a criterion in the classification of aerobic actinomycetes. Int J Syst Bacteriol 20, 435-443.

Lechevalier, M. P., De Bièvre, C. \& Lechevalier, H. A. (1977). Chemotaxonomy of aerobic actinomycetes: phospholipid composition. Biochem Ecol Syst 5, 249-260.

Lee, S. D., Kim, E. S., Roe, J.-H., Kim, J.-H., Kang, S.-O. \& Hah, Y. C. (2000). Saccharothrix violacea sp. nov., isolated from a gold mine cave, and Saccharothrix albidocapillata comb. nov. Int J Syst Evol Microbiol 50, 1315-1323.

Lemmer, H. \& Kroppenstedt, R. M. (1984). Chemotaxonomy and physiology of some actinomycetes isolated from scumming activated sludge. Syst Appl Microbiol 5, 124-135.

Li, W. J. Jiang Y., Kroppenstedt, R. M., Xu, L. H. \& Jiang, C. L. (2004). Nocardia alba sp. nov., a novel actinomycete strain isolated from soil in China. Syst Appl Microbiol 27, 308-312.
MacFaddin, J. F. (1980). Biochemical Tests for Identification of Medical Bacteria, 2nd edn. Baltimore: Williams \& Wilkins.

Maldonado, L., Hookey, J. V., Ward, A. C. \& Goodfellow, M. (2000). The Nocardia salmonicida clade, including descriptions of Nocardia cummidelens sp. nov., Nocardia fluminea sp. nov. and Nocardia soli sp. nov. Antonie van Leeuwenhoek 78, 367-377.

Mesbah, M., Premachandran, U. \& Whitman, W. B. (1989). Precise measurement of the $\mathrm{G}+\mathrm{C}$ content of deoxyribonucleic acid by highperformance liquid chromatography. Int J Syst Bacteriol 39, 159-167.

Minnikin, D. E. M. (1988). Isolation and purification of mycobacterial wall lipids. In Bacterial Cell Surface Techniques, pp. 125-135. Edited by I. C. Hancock \& I. R. Poxton. Chichester: Wiley.

Minnikin, D. E., Alshamaony, L. \& Goodfellow, M. (1977). Differentiation of Mycobacterium, Nocardia, and related taxa by thin layer chromatographic analysis of whole-cell methanolysates. J Gen Microbiol 88, 200-204.

Minnikin, D. E., Hutchinson, I. G., Caldicott, A. B. \& Goodfellow, M. (1980). Thin layer chromatography of methanolysates of mycolic acid-containing bacteria. J Chromatogr 188, 221-233.

Saddler, G. S., Tavecchia, P., Lociuro, S., Zanol, M., Colombo, E. \& Selva, E. (1991). Analysis of madurose and other actinomycete whole cell sugars by gas chromatography. J Microbiol Methods 14, 185-191.

Saitou, N. \& Nei, M. (1987). The neighbor-joining method: a new method for reconstructing phylogenetic trees. Mol Biol Evol 4, 406-425.

Shirling, E. B. \& Gottlieb, D. (1966). Methods for characterization of Streptomyces species. Int J Syst Bacteriol 16, 313-340.

Staneck, J. L. \& Roberts, G. D. (1974). Simplified approach to identification of aerobic actinomycetes by thin-layer chromatography. Appl Microbiol 28, 226-231.

Thompson, J. D., Gibson, T. J., Plewniak, F., Jeanmougin, F. \& Higgins, D. G. (1997). The ClUSTAL $X$ windows interface: flexible strategies for multiple sequence alignment aided by quality analysis tools. Nucleic Acids Res 25, 4876-4882.

Uchida, K. \& Aida, K. (1984). An improved method for the glycolate test for simple identification of the acyl type of bacterial cell walls. J Gen Appl Microbiol 30, 131-134.

Yassin, A. F., Rainey, F. A. \& Steiner, U. (2001). Nocardia ignorata sp. nov. Int J Syst Evol Microbiol 51, 2127-2131.

Zhang, J., Liu, Z. \& Goodfellow, M. (2003). Nocardia caishijiensis sp. nov., a novel soil actinomycete. Int J Syst Evol Microbiol 53, 999-1004. 